\title{
College English Teaching under Guidance of Input and Output Theory \\ Song $\mathrm{Hu}$ \\ School of Foreign Languages, Dalian Jiaotong University, Dalian, 116021, China
}

\begin{abstract}
This paper starts from input and output theory of second language acquisition to propose several suggestions on improving teaching method through analysis on current situation of China's college English teaching for the purpose of improving the teaching effect of college English.

Key words: input and output theory; college English teaching; teaching effect
\end{abstract}

\section{Current situation of China's college English teaching}

As the most popular language, English plays an increasingly important bridge role in interpersonal communication. With China's increasingly high political and economic position in global scale, the cultivation of English talents is especially important. English teaching, as an important means to improve students' English expression ability, attracts more and more people's attention.

Over a long time, China's college English teaching is teachers' instruction-centered, and the students always have passive "learning" and become the objects to which the teachers infuse knowledge. Moreover, as for teachers' teaching effect and students' learning effect, the students' examination performance is always regarded as the only measurement standard. Therefore, the problems such as "examination-oriented", "time-consuming and low-efficiency", and "dumb English,"[7] commonly occur, and students' English listening, speaking, and translation ability far lag. This traditional duck-stuffing teaching method is not only boring, but also throttles students' enthusiasm in independently learning language and violates objective laws of language learning, thus it is not good for cultivating students' English comprehensive ability. When the language teaching becomes examination-oriented and exercise-stuffed, the students will gradually lose their learning innovation and independence, and their personalized development is also greatly limited. Besides, due to continuous increase of enrollment in many colleges, the problems such as seriously insufficient teaching staff, seriously aging teaching equipments, and tight teaching condition are caused. The traditional teaching method of "one chalk, one blackboard" is still in use, which is undoubtedly a heavy blow to students who are under information era and easily accept new things, thus it is hard to stimulate students' learning enthusiasm.

The above conditions propose a challenge to college English teaching. We can't keep silent, but shall make change to break the restrictions of traditional teaching method; to seek for new teaching means is extremely urgent.

\section{Language input and output theory}

The language input and output theory is always a problem which attracts key attention in research of second language acquisition. As early as in 1970s 1980s, the famous linguists Krashen and Swain proposed Input Hypothesis and Output Hypothesis respectively. Krashen pointed out that there was only one way for people to acquire language and understand information, that is, "Comprehensible Input”. He thought that the language acquisition could happen only when the language acquirer accepted "Comprehensive Input", that is, second language input slightly higher than his current language skill level, and he could focus attention on meaning understanding rather than formal understanding. In other words, if the language learner currently has a level of "i”, we 
shall provide the input of level "i+1". Generally speaking, while the language learners accept input, due to limited memory capacity, they will abandon language upon understanding the content for the convenience of accepting new language information. In this way, if there is excessive new knowledge included in language input, the learners may abandon all language knowledge due to their failure in handling and understanding. Therefore, a series of problems are proposed for foreign language educators: how to get control of input quantity of language, how to enrich input form of language and then improve language input level, and how to stimulate students' interest and enthusiasm in language learning in English teaching.

The language input is actually the key and necessary condition for language acquisition, but not the only factor. In 1985, Canadian linguist Swain proposed “Comprehensive Output theory” based on the "input theory" proposed by Krashen, and he thought that the learners should have chance to use the language they learnt except for necessary comprehensive input so that it was possible to reach fluent level similar to native speakers. In other words, the learners shall apply the language resources they have obtained; after obtaining the practice chance of "Comprehensive Output", they can enhance and consolidate the content they have learnt. Swain also pointed out that the teachers' driving function was necessary in the process of students' language output. It is just this "driving" that forces students to further analyze deep-level problems of language such as grammatical structure and then produces the effect of exceeding current language ability.

The input and output of language supplement each other and they are inseparable. Without input, the learners will gain nothing; without output, the learners will be unable to truly master the language due to lack of practice. Therefore, the learners can realize the goal of flexibly applying the language only after there is a virtuous cycle of input and output under balanced state.

\section{Improvement of college English teaching method}

Although it is stipulated in College English Curriculum Requirements published in 2007: "The teaching objective of college English is to cultivate students’ English comprehensive application ability so that they can effectively use English to carry out oral and written information exchange in later study, work, and social contact, as well as to enhance their independent learning ability, and improve comprehensive literal quality to adapt to the demand of China's social development and international communication." ${ }^{,[4]}$, the teachers' classroom teaching still remains at elementary stage of instructing language knowledge, and the teachers only apply grammar translation method to guide teaching in practice. The unreasonable quality and quantity of input information and the single input form result in great problems in students' information input process.

Therefore, the improvement of college English teaching method is extremely urgent.

3.1 To promote listening, speaking, reading, and writing ability as a whole

The listening and reading are main means of language input, and the speaking and writing are the representation form of language output. In English teaching process, we divide listening \& speaking and reading \& writing into two independent courses. However, in reading and writing classroom, most of teachers still use excessive classroom time to carry out English reading training, but ignore the cultivation of English writing ability; in listening and speaking classroom, the teachers only pay attention to English listening training, and seriously ignores the "speaking" link, which causes serious imbalance between students' language input and output. The teaching mode is single, the classroom climate is depressing, and the knowledge the students have learnt can't be changed into practical ability. Therefore, we advocate that teachers shall pay attention to 
output link of language in classroom teaching, and let students become the masters of classroom so as to improve the output efficiency of language. The listening ability shall be practiced together with speaking ability, and the reading ability shall be practiced together with writing ability so that they can promote each other and it is able to achieve the balance of four abilities.

3.2 To introduce multimedia teaching mode

Over many years, we always adopt old teaching mode, that is, the teachers make continuous instructions and blackboard-writing in classroom, and the teaching method is single and boring. With the development of modern science and technology, the multimedia and network have provided students with sound and images in teaching process, which more or less makes up some deficiencies in traditional teaching means. This new teaching means not only can effectively motivate students' learning enthusiasm, but also makes students' English learning become more personalized and active due to no limitations of time and place on network.

3.3 To utilize the second classroom to enrich students' English learning

The limited classroom time makes English learning lack of consistency. Due to many students in classroom, to make each student have enough language use environment becomes a task which can't be completed. Therefore, it is able to solve this problem via helping students to make use of after-class time to organize some English-related extracurricular activities and carry out construction of second classroom. For example, it is able to fully exert the function of students' association to hold English speech contest, English stage play, English movie dubbing competition, English salon, and campus English broadcast. Those activities not only can create an English learning atmosphere for students, but also can enrich students' after-school life and can provide students with English practice platform, thus it can be said that many things are achieved at one stroke.

3.4 To perfect and enhance teachers' role change

Nowadays, as more and more attention is paid to balanced development of various abilities in English learning, the transition of teacher's role is also worth our research and discussion. In old teaching mode, the teachers are the subject of classroom; after class, there lacks of communication between college teachers and students. It is obvious that this condition is neither good for balanced development of students' language ability, nor good for forming a virtuous cycle of language input and output. Therefore, we advocate that the students shall become the subject of classroom; after class, the teachers shall become the guider to guide students to carry out independent learning. Furthermore, the teaching shall become "education"; while the teachers improve their quality, the teaching shall be able to educate students and make them realize an integrated development.

\section{Conclusion}

The application of input and output theory into specific English listening, speaking, reading, and writing course teaching can timely and effectively change the traditional language input form, and make learners realize a balanced language input (listening and reading) and output (speaking and writing) in whole teaching process so as to promote students' integrated development of all skills in English learning and improve students' language comprehensive utilization ability. The college English is a required course that each college student shall learn for at least two years. How to stimulate students' interest in foreign language learning within limited classroom time, and how to utilize the advantage that college students have flexible and sufficient extracurricular disposable time to encourage them to carry out independent learning and exploring learning so as to realize 
the true value of English learning are of great practical significance for English teaching reform.

\section{References}

[1]Krashen,S. Pvinciples and Practice in the Language Classroom. Oxford: Pergamon, 1982.

[2]Swain, M.Communicative Competence: Some roles of compresible input and comprehensible in its development $(M)$. Rowley. MA: Newbury House:1985.

[3] Liu Runqing: English Educational Research [M], Background: Foreign Language Education and Research Press, 2004.

[4] Department of Higher Education of Ministry of Education: College English Curriculum Requirements [Z], Shanghai Foreign Language Education Press, 2007.

[5] Wen Qiufang: Three Basic Problems on Tracking Study of Second Language Acquisition: Classification, Design, and Possibility [J], Foreign Language in China, 2009 (2): p54-60.

[6] Luo Lisheng: Krashen's Language Input Theory and Foreign Language Teaching [J], Tsing Hua Journal of Chinese Studies, 2001 (4).

[7] Hu Zhuanglin: “Low-efficiency” Problem in China’s English Teaching [J], Foreign Language Teaching, 2002 (4): p3-7.

[8] Xiang Maoying: Influence of Emotional Factors on College English Teaching, Foreign Languages and Their Teaching, 2003 (3): p23-26.

[9] Cai Jigang: Several Thoughts on College English Teaching [J], Foreign Language Teaching and Research, 2005 (2).

[10] Ding Yanren: Research on Second Language Acquisition and Foreign Language Learning [J], Shanghai Foreign Language Education Press, 2004. 